\title{
2017, Vol. 6, Issue 1
}

\section{EUROPEAN AGENCIES' HEADQUARTERS AGREEMENTS}

\section{Marek Zieliński*}

Keywords: EU Agencies; EU law; headquarters agreements Abstract: The article examines headquarters agreements concluded by European Agencies (EA) with EU host Member States. This sort of agreement is increasingly visible in practice, as it regulates the status of EAs present within a host state territory. After presenting a list of existing headquarters agreements and describing their content, the article analyses the legal bases for their conclusion. Finally, the legal character of EU agencies' headquarters agreements, and the position occupied by them within the sources of EU law, are explained. The author considers three possible options regarding the legal nature of the agreements: treaties, administrative agreements and public law contracts. The final conclusion is that EA headquarters agreements are international treaties concluded by EAs in the name of the EU with host Member States.

\section{Introduction}

Headquarters agreements concluded between states and international organisations (seat agreements, host agreements), are important

* Professor, University of Silesia in Katowice, Department of Public International Law and European Law 
preconditions regulating their relations with their host states ${ }^{1}$. This sort of agreement in particular specifies the unique status enjoyed by international organisations within the legal order of the receiving states, with the aim of allowing them to perform their functions undisturbed ${ }^{2}$. More recently, headquarters agreements have also been used as instruments of human resources management policy, as they increasingly affect the financial benefits and life arrangements of the staff of international organisations as well as the members of their families ${ }^{3}$.

Apart from international organisations, headquarters agreements have been concluded by the states with secretariats of some Multilateral Environmental Agreements ${ }^{4}$ and international tribunals ${ }^{5}$. The complexification of the United Nations' organisational structure ${ }^{6}$ entailed a practice whereby headquarters agreements are also concluded by some of their subsidiary organs, e.g. the United Nations High Commissioner for Refugees $(\mathrm{UNHCR})^{7}$ and the High Commissioner for Human Rights (HCHR) ${ }^{8}$.

1 A. S. Muller, International Organizations and their Host States. Aspects of their Legal Relationship, Kluwer Law International, The Hague 1995, D. B. Michaels, International Privileges and Immunities: a Case for a Universal Statute, Martinus Nijhoff, The Hague 1971, K. Ahluwalia, The Legal Status, Privileges and Immunities of the Specialised Agencies of the United Nations and Certain other International Organizations, Martinus Nijhoff, The Hague 1964.

2 A. S. Muller, op. cit., p. 21.

3 W. Münch, The Impact of Headquarters Agreements on Human Resources Management of the United Nations System, [in:] S. von Scholremer (ed.), 'Praxishandbuch UNO', Springer, Berlin Heidelberg New York 2003, p. 644.

4 R. R. Churchill, G. Ulfstein, Autonomous Institutional Arrangements in Multilateral Environmental Agreements: a Little Noticed Phenomenon in International Law, 'American Journal of International Law' 2000, vol. 94, no. 4, p. 623.

5 See, for example, the agreement between the Federal Republic of Germany and the International Tribunal for the Law of the Sea regarding the Headquarters of the Tribunal, Berlin 14.12.2004, UNTS vol. 2464, no. 44269.

6 P. C. Szasz, The Complexification of the United Nations System, 'Max Planck Yearbook of United Nations Law' 1999, no. 3, p. 1.

7 See, for example, the United Nations (United Nations High Commissioner for Refugees) and Jordan, Agreement on the establishment of a United Nations High Commissioner for Refugees field office in Jordan, Amman, 30.7.1997, UNTS vol. 1984, no. I-33952, Cooperation Agreement between the Office of the United Nations High Commissioner for Refugees and the Government of the Democratic Republic of East Timor, Dili 20.5.2002, UNTS vol. 2185, no. II-1248.

8 United Nations (Office of the High Commissioner for Human Rights) and Senegal, Headquarters Agreement between the United Nations High Commissioner for Human 
Within the institutional framework of the EU and EAEC the 'pluralisation' process, seen as the proliferation of their institutions and organs endowed with distinct legal personality ${ }^{9}$, has prompted some of them to conclude headquarters agreements with their host Member States $^{10}$. As a part of the pluralisation, the ongoing agencification of the EU executive ${ }^{11}$ also resulted in the flourishing of EA headquarters agreements ${ }^{12}$. This phenomenon was noticed in scholarly literature as early as in $2004^{13}$, but since has undergone considerable development with respect to its scale as well as conceptualisation. As far as the former is concerned, according to the Commission there are currently only seven EAs that do not have proper headquarters agreements ${ }^{14}$. As far as the latter is concerned, in the Common Approach of 2012, annexed to the Joint Statement of the European Parliament, the Council and the European Commission, the institutions agreed that, 'All agencies should have headquarters agreements, which should be concluded before the agency starts its operational phase. Agencies still lacking a headquarters agreement and the host country in question should reach an agreement in accordance with the legal order of the relevant Member State [...] ${ }^{15}$. The Common Approach calls on the Commission to 'put together a set of provisions

Rights and the Government of the Republic of Senegal concerning the establishment of a Regional Office of the United Nations High Commissioner for Human Rights for West Africa in Dakar, 3.12.2007, UNTS, vol. 2484, no. 44594.

9 M. Ruffert, Personality under EU Law: A Conceptual Answer towards the Pluralisation of the EU, 'European Law Journal' 2014, vol. 20, no. 3, p. 346.

10 European Central Bank with Germany (Abkommen zwischen der Regierung der Bundesrepublik Deutschland und der Europäischen Zentralbank über den Sitz der Europäischen Zentralbank, Bundesgesetzblatt 1998 Teil II, no. 51, p. 2996), and European Joint Undertaking for ITER and the Development of Fusion Energy with Spain (Host Agreement on Site and Support, Privileges and Immunities between the Kingdom of Spain and the European Joint Undertaking for ITER and the Development of Fusion Energy), available at: http://fusionforenergy.europa.eu/downloads/aboutf4e/decisions/ Decision_4.pdf [last accessed: 4.04.2017].

11 H. C. H. Hofmann, A. Morini, Constitutional aspects of the pluralisation of the EU executive through "agencification", 'European Law Review' 2012, vol. 37, no. 4, p. 421.

12 M. Chamon, EU Agencies. Legal and Political Limits to the Transformation of the EU Administration, Oxford University Press, Oxford 2013, pp. 93-97.

13 G. Schusterschitz, European Agencies as Subjects of International Law, 'International Organizations Law Review' 2004, no. 1, p. 172.

14 Report from the Commission, "Progress report on the implementation of the Common Approach on EU decentralised agencies", $\operatorname{COM(2015)~179,~p.~} 3$.

15 "Common Approach on EU decentralised agencies", para 9. 
on the basis of existing best practices, to serve as a good orientation tool for future headquarters agreements ${ }^{16}$. On this basis, the Commission prepared 'Guidelines with standard provisions for headquarters agreements of the EU decentralised agencies', which aim to support EAs and Member States 'by providing a model that they should consider upon negotiating a new headquarters agreement, or upon revising an existing one ${ }^{\text {,17. }}$. The Commission is also aware of EAs' legal independence, and that they alone are responsible for the way they deal with this question in practice. Careful analysis of the existing headquarters agreements proves, however, that in some cases EAs are 'too independent', which entails such a great variety of headquarters agreements that on the one hand it runs counter to the original aim of the Commission, and on the other, they seem to be even contrary to the rules of EU law. In the author's opinion, the reason for this is that the legal nature of EA headquarters agreements is not explained anywhere. Neither existing EU law, nor scholarly literature have provided convincing clarification as to their legal character or status in the hierarchy of sources of EU law. The existing case law also gives little guidance, as this problem has never yet been analysed by the Court of Justice of the European Union (CJEU).

This article, therefore, aims to present EA headquarters agreements and to explain their legal nature. It also attempts to place them within the framework of sources of EU law. The author's basic assumption is that, regardless of their form, content and the procedures leading to their conclusion, all EA headquarters agreements should be treated as having the same legal character. The structure of the article is as follows. The article opens with a presentation of EA headquarters agreements identified by the author (in force as well as expired), then the legal bases for their conclusion are explained and their content is described. The following section aims to identify the legal character of EA headquarters agreements, where three options will be considered (treaties, public law contracts and administrative agreements). The final section will summarise the article and present some postulates de lege ferenda.

16 Ibid., para 9.

17 http://europa.eu/european-union/sites/europaeu/files/docs/body/2013-12-10_ guidelines_hq_agreements_en.pdf [last accessed 4.04.2017]. 


\section{List of EA Headquarters Agreements} far:

The following EA headquarters agreements have been concluded so

- European Training Foundation and Italy (ETF-I) of 19.12.1994 ${ }^{18}$;

- European Environmental Agency and Denmark (EEA-DK) of $10.5 .1995^{19}$;

- European Monitoring Centre for Drugs and Drug Addiction and Portugal (EMCDDA-P) of 26.6.1996 ${ }^{20}$;

- European Police Office and the Netherlands (Europol-NL) of $15.10 .1998^{21}$ and Additional Protocol of 24.10.2007 ${ }^{22}$;

- European Monitoring Centre for Racism and Xenophobia and Austria (EMCR-A) of 18.5.2000

- European Agency for Reconstruction and Greece (EAR-GR) of 26.6.2000

- European Food Safety Authority and Italy (EFSA-I) of 27.4.2004 ${ }^{25}$;

- European Aviation Security Agency and Germany (EASA-D) of 14.5.2004 ${ }^{26}$; European Maritime Safety Agency and Portugal (EMSA-P) of 28.7.2004 ${ }^{27}$;

- European Police College and United Kingdom (CEPOL-UK) of 30.12.2004 ${ }^{28}$;

- European Network and Information Security Agency and Greece (ENISA-GR) of 22.4.2005'

18 Gazzetta Ufficiale, no. 100, 2.5.1997.

19 UNTS vol. 1889, no. 32150, p. 311.

20 Diário da República - I Série-Á, no. 124, 29.5.1998.

21 Tractatenblad, 1998, no. 241.

22 Tractatenblad, 2008, no. 21.

${ }^{23}$ Bundesgesetzblatt für die Republik Österreich, Teil III, 84/2001.

24 Efimeris tis Kyverniseos, no. 76, 12.4.2001, p. 1427.

25 Gazzetta Ufficiale, no. 21, 26.1.2006.

26 Verwaltungsabkommen zwischen der Regierung der Bundesrepublik Deutschland und der Europäischen Agentur für Flugsichercheit and supplemental exchange of correspondence between EASA and Bundesministerium für Verkehr, Bau und Wohnungswesen of 16.7.2004 (on file with the author).

27 Diário da República - I Série-Á, no. 224, 22.9.2004, p. 6073

28 Treaty Series no. 9 (2005).

29 Efimeris tis Kyverniseos, no. 125, 8.7.2007, p. 2873. 
- $\quad$ Eurojust and the Netherlands (Eurojust-NL) of $15.3 .2006^{30}$;

- European Agency for the Management of Operational Cooperation at the External Borders of the Member States of the EU and Poland (Frontex-PL(1)) of 26.3.2007 ${ }^{31}$;

- European Chemicals Agency and Finland (ECHA-FIN) of 28.6.2007

- European Fisheries Control Agency and Spain (EFCA-E) of 19.7.2008 ${ }^{33}$;

- Fundamental Rights Agency and Austria (FRA-A) of $16.6 .2010^{34}$;

- European Centre for Disease Prevention and Control and Sweden (ECDC-S) of 30.6.2010

- Frontex and Greece - on the seat of the Frontex Operational Office (Frontex-GR) of 2.8.2010 ${ }^{36}$;

- Agency for the Cooperation of Energy Regulators and Slovenia (ACER-SLO) of 26.11.2010

- Office of the Body of European Regulators for Electronic Communications and Latvia (BEREC-LV) of 24.11.20118;

- European Asylum Support Office and Malta (EASO-M) of 24.5.2011

- European Union (Office for Harmonization in the Internal Market) and Spain (OHIM-E) of 20.9.2011 ${ }^{40}$;

Tractatenblad, 2006, no. 68.

31 On file with the author. It should be mentioned that, according to the Commission, this is not a headquarters agreement proper, but merely a non-binding 'Memorandum of Understanding'. The author does not share this opinion. The Frontex-PL seat agreement contains a number of provisions that are binding on their parties (Poland especially) and may be regarded as having legal force. On that point see M. Zieliński, Porozumienie dotyczace siedziby agencji Unii Europejskiej Frontex w Polsce (aspekty konstytucyjne) [The Agreement on the Seat of EU Agency Frontex in Poland (Constitutional Aspects)], 'Przegląd Sejmowy' 2016, vol. XXIV, no. 1(132), p. 53.

32 Suomen Säädöskokoelman Sopimussarja, 2008 no. 10-11, p. 90.

33 Boletín Oficial del Estado, no. 230, 23.9.2008. Sec. I. Pág. 38648.

34 Bundesgesetzblatt für die Republik Österreich, Teil III, 10/2011.

35 Sveriges internationella överenskommelser, SÖ 2011: 3.

36 Efimeris tis Kyverniseos, no. 216, 23.12.2010, p. 4450.

37 Uradni list Republike Slovenije, št. 22, 30.12.2010, p. 1999.

38 Latvijas Vēstnesis, no. 99 (4497), 29.6.2011.

39 http://easo.europa.eu/wp-content/uploads/Seat-Agreement.pdf (accessed 10.3.2016).

40 Boletín Oficial del Estado, no. 254, 21.10.2011. Sec. I. Pág. 110030. 
- European Insurance and Occupational Pensions Authority and Germany (EIOPA-D) of 18.10.2011 ${ }^{41}$;

- European Global Navigation Satellite System Agency and the Czech Republic (GNSS-CZ) of 27.1.2012 ${ }^{42}$;

- European Banking Authority and the United Kingdom (EBA-GB) of 8.5.2012 $2^{43}$;

- $\quad$ European Institute for Gender Equality and Lithuania (EIGE-LT) of 22.10.2012

- European Agency for the Operational Management of LargeScale IT Systems in the Area of Freedom, Security and Justice and Austria (eu-LISA - A) of 27.5.2013 ${ }^{45}$;

- European Union (European Agency for Safety and Health at Work) and Spain (EU-OSHA-E) of 31.3.2014 ${ }^{46}$;

- $\quad$ CEPOL and Hungary (CEPOL-H) of 18.8.2014 ${ }^{47}$;

- $\quad$ eu-LISA and Estonia (eu-LISA - EST) of 14.12.2014 ${ }^{48}$;

- European Union (European Foundation for the Improvement of Living and Working Conditions) and Ireland (Eurofound - IRL) of $10.11 .2015^{49}$;

- European Border and Coast Guard Agency and Poland (FrontexPL(II)) of 9.3.2017 ${ }^{50}$.

\section{Legal Bases for EA Headquarters Agreements}

The first condition for the legality of an agreement in EU law is the competence to conclude $\mathrm{it}^{51}$. The most important single legal basis for EA headquarters agreements may be found in Article 18 of Protocol

41 Bundesgesetzblatt. Teil II, no. 12/2012, p. 339.

42 Sbírka mezinárodních smluv č. 74/2012, p. 1626.

43 Treaty Series no. 29 (2012).

44 On file with the author.

45 Bundesgesetzblatt für die Republik Österreich, Teil III, 279/2013.

46 Boletín Oficial del Estado, Núm. 119, 16.5.2014. Sec. I. Pág. 38049.

47 Magyar Közlöny, 2014. évi 137. szám 19393.

48 Riigi Teataja II, 6.3.2015, 2.

49 Statutory Instruments, S.I. no. 428 of 2016.

50 Not in force yet. On file with the author.

51 H. C. H. Hofmann, Agreements in EU Law, 'European Law Review' 2006, vol. 31, no. 6 , p. 804 . 
No. 7 on the Privileges and Immunities of the EU (PPI) ${ }^{52}$. This has been confirmed in the preambles to most of the EA headquarters agreements. In EU secondary law, the legal basis for EA headquarters agreements appeared for the first time in 2004 with the adoption of Decision 2004/567/ $\mathrm{JHA}^{53}$, amending a decision establishing CEPOL. According to its Article 1, the CEPOL-UK seat agreement was to set out the necessary arrangements concerning the accommodation to be provided for CEPOL in the UK, and the facilities to be made available by the UK, as well as particular rules applicable to members of CEPOL's governing bodies, its administrative director, employees and members of their families ${ }^{54}$. In 2009, similar provisions were introduced into Decision 2009/371/ $\mathrm{JHA}^{55}$, which transformed Europol into a genuine EA. It is rather clear that the basis for headquarters' agreements were inserted into the Europol decision because similar provisions could be found earlier in the Europol Convention ${ }^{56}$. The adoption of the Europol decision gave some impulse for placing almost identical rules into acts establishing other EAs. Thus, in 2010, seat agreement provisions were added with the adoption of regulations establishing the $\mathrm{EASO}^{57}$,

52 "The institutions of the Union shall, for the purpose of applying this Protocol, cooperate with the responsible authorities of the Member States concerned."

53 Council Decision 2004/567/JHA amending Decision 2000/820/JHA establishing a European Police College (CEPOL), OJ 27.7.2004 L-251, p. 20.

54 Currently see: Regulation (EU) No. 2015/2219 of the European Parliament and of the Council on the European Union Agency for Law Enforcement Training (CEPOL) and replacing and repealing Council Decision 2005/681/JHA, OJ 4.12.2015, L-319, p.1, Article 35.

55 Council Decision 2009/371/JHA establishing the European Police Office (Europol), OJ 15.5.2009, L-121, p. 37, Article 50. Currently see: Regulation (EU) No. 2016/794 of the European Parliament and of the Council on the European Union Agency for Law Enforcement Cooperation (Europol) and replacing and repealing Council Decisions 2009/371/JHA, 2009/934/JHA, 2009/935/JHA and 2009/968/JHA, OJ 24.5.2016, L-135, p. 53, Article 70.

56 Council act drawing up the Convention based on art K.3 of the Treaty on European Union on the establishment of a European Police Office (Europol Convention), OJ 27.11.1995, C-316, p. 1, Article 26.

57 Regulation (EU) No. 439/2010 of the European Parliament and of the Council establishing a European Asylum Support Office, OJ 29.5.2010, L-132, p. 11, Article 53. 
$\mathrm{EBA}^{58}$, EIOPA ${ }^{59}$ and European Securities and Markets Authority (ESMA) ${ }^{60}$. Further, in 2011, a headquarters agreement clause was also inserted into the regulation establishing eu-LISA ${ }^{61}$, enabling it to conclude agreements on its seat with Estonia, and on the technical and backup sites with France and Austria. With the amendment of the regulation establishing Frontex in 2011, a new Article 15a was added providing for the conclusion of headquarters agreements ${ }^{62}$. In 2014, a provision on headquarters agreements was added to the regulation on the GNSS Agency that enables it to "make specific arrangements" relating to the installation and operation of the agency in host Member States and host third countries ${ }^{63}$. The regulation on the Single Resolution Board (SRB) provides for a headquarters agreement with Belgium, concluded after obtaining the approval of the SRB Board in its plenary session, and no later than 20.8.2016 ${ }^{64}$.

58 Regulation (EU) No. 1093/2010 of the European Parliament and of the Council establishing a European Supervisory Authority (European Banking Authority), amending Decision no. 716/2009/EC and repealing Commission Decision 2009/78/EC, OJ 15.12.2010, L-331, p. 12, Article 74.

59 Regulation (EU) No. 1094/2010 of the European Parliament and of the Council establishing a European Supervisory Authority (European Insurance and Occupational Pensions Authority), amending Decision 716/2009/EC and repealing Commission Decision 2009/79/EC, OJ 15.12.2010, L-331, p. 48, Article 74.

${ }^{60}$ Regulation (EU) No. 1095/2010 of the European Parliament and of the Council establishing a European Supervisory Authority (European Securities and Markets Authority), amending Decision no. 716/2009/EC and repealing Commission Decision 2009/77/EC, OJ 15.12.2010, L-331, p. 84, Article 74.

61 Regulation (EU) No. 1077/2011 of the European Parliament and of the Council establishing a European Agency for the operational management of large-scale IT systems in the area of freedom security and justice, OJ 1.11.2011, L-286, p. 1, Article 10.

62 Regulation (EU) No. 1168/2011 of the European Parliament and of the Council amending Council Regulation (EC) No. 2007/2004 establishing a European Agency for the Management of Operational Cooperation on the External Borders of the Member States of the European Union, OJ 22.11.2011, L-304, p. 1. Currently see: Regulation (EU) No. 2016/1624 of the European Parliament and of the Council on the European Border and Coast Guard and amending Regulation (EU) No. 2016/339 of the European Parliament and of the Council and repealing Regulation (EC) No. 863/2007 of the European Parliament and of the Council, Council Regulation (EC) No. 2007/2004 and Council Decision 2005/267/EC, OJ 16.9.2016, L-251, p. 1, Article 57.

${ }_{63}$ Regulation (EU) No. 512/2014 of the European Parliament and of the Council amending Regulation (EU) No. 912/2010 setting up the European GNSS Agency, OJ 20.5.2014, L-150, p. 72, Article 1, para. 1.

${ }^{64}$ Regulation (EU) No. 806/2014 of the European Parliament and of the Council establishing uniform rules and a uniform procedure for the resolution of credit 
It should also be observed that in the Frontex case, the legal basis for the headquarters agreement resulted also from its Management Board Decision no. 1/2010 allowing for setting up Frontex Operational Offices $(\mathrm{OO})^{65}$, based on Article 16 of the Frontex regulation providing for setting up specialised branches in the Member States ${ }^{66}$. According to Article 5 of that decision, before setting up Frontex OO, the executive director has to conclude proper headquarters agreements with each of the Member States hosting it. Each headquarters agreement has to ensure, in an appropriate way, the efficient working conditions and integrity of the Frontex OO.

Finally, it must be mentioned that there are also EAs whose basic acts indirectly exclude the possibility of concluding headquarters agreements, as they provide for a different way of granting them privileges and immunities in the Member States. According to the decisions establishing the European Defence Agency ${ }^{67}$ (EDA), the European Union Institute for Security Studies ${ }^{68}$ (EUISS), the European Union Satellite Centre ${ }^{69}$ (EUSC), the privileges and immunities of their chief executive and staff members are to be provided for in the decisions of the representatives of the Governments of the Member States meeting within the Council, and the privileges and immunities of these EAs are provided for in the PPI. These decisions were taken with respect to the EDA on 10.11.2004 $4^{70}$ and to the EUISS and EUSC on $15.10 .2001^{71}$, but they are not in force yet. Pending

institutions and certain investment firms in the framework of a Single Resolution Mechanisms and a Single Resolution Fund and amending Regulation (EU) No. 1093/2010, OJ 30.7.2014, L-225, p. 1, Article 97.

65 Management Board Decision no. 1/2010 of 4.2.2010, setting up Frontex operational offices (on file with the author).

66 In 2008, the European Council called on Frontex to set up such 'specialised offices', see European Pact on Immigration and Asylum, 24.9.2008, 13440/08, point III(c).

67 Council Decision (CFSP) 2015/1835 defining the statute, seat and operational rules of the European Defence Agency (recast), OJ 13.10.2015, L-266, p. 55, Article 25.

68 Council Decision 2014/75/CFSP on the European Union Institute for Security Studies, OJ 12.2.2014, L-41, p. 13, Article 13.

69 Council Decision 2014/401/CFSP on the European Union Satellite Centre and repealing Joint Action 2001/555/CFSP on the establishment of a European Union Satellite Centre, OJ 27.6.2014, L-188, p. 73, Article 13.

70 Decision of the representatives of the Governments of the Member States, meeting within the Council, on the privileges and immunities granted to the European Defence Agency and to its staff members, Brussels, 9.9.2004, 11502/04.

${ }^{71}$ Decision of the Representatives of the Governments of the Member States of the European Union, meeting within the Council on the privileges and immunities 
the ratification of the respective Decision by the Member States, the EDA concluded an 'Additional Protocol' with Belgium on 22.6.2005 ${ }^{72}$, which can be regarded as the EDA's headquarters agreement. According to its Article 1, in Belgium the EDA and its staff enjoy privileges and immunities provided for in the Decision of the representatives of Governments of the Member States of 10.11.2004, which is annexed to the Additional Protocol.

\section{Content of EA headquarters agreements}

The subjects of EA headquarters agreements vary in some respects, but there are several typical clauses that are contained in almost all these agreements.

\subsection{Preamble}

In most cases, EA headquarters agreements include preambles that primarily lay down motives for their conclusion and confirm that the underlying reason for the headquarters agreement is the need to construe further provisions necessary to implement certain provisions of the PPI, and for additional matters to render the EA fully operational. In some cases, the preamble confirms the applicability to the EA of 'Modalities of Application of the PPI' concluded between the Government of a given Member State and the European Commission (European Communities) ${ }^{73}$. Some headquarters agreements concluded by Spain ${ }^{74}$ invoke the 'declaration' made by the Commission concerning the exceptional legal capacity of a given EA enabling it to conclude a headquarters agreement ${ }^{75 .}$ Exceptionally,

granted to the European Union Institute for Security Studies and the European Union Satellite Centre, and to their bodies and staff members, Brussels, 19.9.2001, 11639/01.

72 On file with the author.

73 With respect to Poland, see the Agreement between the Government of the Republic of Poland and the European Communities implementing the Protocol on the Privileges and Immunities of the European Communities signed in Brussels on 8.4.1965, done at Brussels 13.4.2005, Polish OJ 2005, No. 193, Item 1614.

74 OHIM-E, EU-OSHA-E.

75 With respect to the EU-OSHA, see the European Commission (Employment, Social Affairs and Inclusion DG) Letter to the Permanent Representative of Spain 
preambles may also comprise some definitions drawn up for the purposes of a given headquarters agreement ${ }^{76}$.

\subsection{Definitions}

Most headquarters agreements include definitions of the terms used in the text. In addition to typical definitions explaining notions such as 'Protocol', 'Government' and 'family members', many headquarters agreements set out definitions of 'archives" ${ }^{\text {'77 }}$ and 'direct taxes ${ }^{178}$.

For the purposes of headquarters agreements, the seat of the EA is usually understood as the 'buildings, installations and land' used by the EA in a given city for its official business, including in particular 'office premises, buildings and archives ${ }^{79}$. Some agreements provide that buildings outside the city of the seat that are used for meetings convened by the EA should be deemed temporarily to form part of the headquarters, under the agreement with the respective Government ${ }^{80}$.

\subsection{Interpretation of headquarters agreements and proper law}

Some headquarters agreements contain provisions regarding the principles of their interpretation and regulating possible conflicts between them and certain sources of EU law. Article 2 of the EBA-GB agreement provides that 'it shall be interpreted in the light of the primary objective of enabling the EBA and its Headquarters in the United Kingdom fully and efficiently to discharge its responsibilities and fulfil its objectives and tasks.' If there is a conflict between the regulation establishing

to the European Union of 8.8.2011, Information Note - Capacity of EU-OSHA to conclude and sign a Headquarters agreement with the Kingdom of Spain, (on file with the author).

76 OHIM-E.

77 Eurojust-NL: Article 1(p), EBA-GB: Article 1(c).

78 EIOPA-D: Article 1(6).

79 ACER-SLO: Article 1(2), BEREC-LV: Article 1(2), EASO-M: Article 16, EBA-GB: Article 1(b), OHIM-E: Article 8.

${ }^{80}$ EFRA-A: Article 2(2), eu-LISA-A: Article 2 (3). 
the EBA and the EBA-GB headquarters agreement, the regulation prevails. Similarly, the Europol-NL agreement states in its Article II that, in the event of a conflict between its provisions and the Protocol on the Privileges and Immunities of Europol, the protocol will prevail ${ }^{81}$.

There are also provisions on the applicable law in some headquarters agreements. According to Article 21 of the eu-LISA - EST agreement, it is governed by and interpreted under EU law, but supplemented where applicable by the laws and regulations of Estonia. Article 17 of the GNSS-CZ agreement says it is subject to international law, which clearly demonstrates that it is viewed by its parties primarily as an international treaty.

\subsection{Legal status of EAs}

The majority of headquarters agreements ${ }^{82}$ state that EAs are bodies of the EU and that they enjoy the most extensive legal capacity accorded to legal persons under the laws of Member States, which is mere confirmation of EAs' legal personality resulting from their establishing acts. It should be underscored, however, that according to Article 3 of the Frontex-GR headquarters agreement, Frontex OO in Pireus was recognised as an integral part of Frontex's organisational structure and had the capacity in Greece to 'act on behalf of Frontex'. This looks as if Frontex, in cooperation with Greece, endowed its subsidiary organ functioning in Greece with legal personality. Frontex OO, however, was to be represented by its Head according to the Frontex Internal Rules of Procedure, which certainly limited its legal independence.

An exceptional and unusual provision was added to Article 1(1) of the EAR-GR headquarters agreement, whereby EAR had 'international legal personality'.

Some headquarters agreements ${ }^{83}$ add that an EA is considered an international organisation within the meaning of directives relating

81 It should, however, be recalled that this protocol was replaced by the decision establishing Europol, see Decision 2009/371/JHA Article 62.

82 Some notable exceptions include: EIOPA, EMSA, EUMC, and Eurojust.

83 GNSS-CZ: Article 3(2). 
to value added $\operatorname{tax}^{84}$, excise duty ${ }^{85}$, certain procurement procedures ${ }^{86}$ and procedures for the award of public contracts ${ }^{87}$.

\subsection{Inviolability of premises and immunities of EAs}

EA headquarters agreements guarantee the inviolability of their premises, and Member States are obliged not to enter the relevant EA premises without prior approval of the individuals designated by them (e.g. Administrative Manager ${ }^{88}$ or Executive Director ${ }^{89}$ ).

Only in exceptional cases requiring prompt protective action (fire or other emergency), can the consent of the designated person to enter the headquarters of the EA be presumed ${ }^{90}$. EA headquarters and its properties are additionally exempt from search, requisition, confiscation or expropriation ${ }^{91}$. The property and assets of EAs are not subject to any administrative or legal measure of constraint without the authorisation of the CJEU ${ }^{92}$.

EAs may enjoy immunity from criminal, civil or administrative jurisdiction or execution, unless they expressly waive such immunity in a particular case ${ }^{93}$. Some headquarters agreements provide for the exclusion of an EA's immunities, particularly with regard to a civil action by a third party for damage caused by a motor vehicle belonging to or operated by an EA, or may restrict the agency's jurisdictional immunity, for example

84 Council Directive 2006/112/EC on the common system of value added tax, OJ 11.12.2006, L-347, p.1, Article 151(1)(b).

85 Council Directive 2008/118/EC concerning the general arrangements for excise duty and repealing Directive 92/12/EEC, OJ 14.1.2009, L-9, p. 12, Article 12 (1) (b).

${ }_{86}$ Directive 2004/17/EC of the European Parliament and of the Council coordinating the procurement procedures of entities operating in the water, energy, transport and postal services sectors, OJ 30.4.2004, L-134, p. 1, Article 22 (c).

87 Directive 2004/18/EC of the European Parliament and of the Council on the coordination of procedures for the award of public works contracts, public supply contracts and public service contracts, OJ 30.4.2004, L-134, p. 114, Article 15 (c).

88 BEREC-LV: Article 4(2).

89 EBA-GB: Article 6(4).

90 Europol-NL: Article III(3).

91 ECDC-S: Article 3.

92 BEREC-LV: Article 4(1), CEPOL-H: Article 5(2), ECDC-S: Article 3, EIGE-LT: Article 3, GNSS-CZ: Article 8(3).

93 GNSS-CZ: Article 8(1). 
in respect of proceedings relating to employment contracts between an EA and a member of its staff ${ }^{94}$.

\subsection{Security at the EAs' premises}

The EAs are usually responsible for the security and the maintenance of order at their seat. For the purpose of exercising this responsibility, EAs may take all measures they deem necessary, and in particular adopt internal rules that are binding on their staff and all visitors ${ }^{95}$. Headquarters agreements usually provide that EAs may refuse access to their buildings and installations, or decide to expel or exclude from them any individuals for a breach of regulations ${ }^{96}$ or if they are considered undesirable ${ }^{97}$. In some cases, EAs may appoint security guards authorised to carry firearms within their premises. The carrying of firearms by security guards should, however, be subject to the host state's legislation ${ }^{98}$. Against this backdrop, the EIOPA-D headquarters agreement stipulates that the EIOPA is responsible for the protection of its premises, but its Executive Director may request the competent police forces to restore law and order within its seat ${ }^{99}$. Hence, it is clear that the EIOPA-D agreement does not provide EIOPA with the possibility to expel or remove from its premises anyone who is considered undesirable, and does not allow it to adopt internal rules for the purpose of preserving order.

Most EA headquarters agreements also contain provisions on assistance and cooperation in security matters between the agency and the host Member State. They provide, in particular, for close cooperation to ensure effective security within and in the immediate vicinity of the EA or the mutual notification of all matters relating to the security of persons and the seat of the $\mathrm{EA}^{100}$.

94 EBA-GB: Article 5(1)(f).

95 ACER-SLO: Article 5(2), BEREC-LV: Article 6(2), EASO-M: Article 5(2), EBA-GB: Article 6(2), ECDC-S: Article 6(2), ECHA-FIN: Article 5(2), EFCA-E: Article 8(2), EFRA-A: Article 6(2).

${ }_{96}$ Eurojust-NL: Article 3(3), OHIM-E: Article 9(2).

97 EMSA-P: Article 8(2).

98 OHIM-E: Article 9(4).

99 EIOPA-D: Article 5(2).

100 EIGE-LT: Article 6. 


\subsection{Exemption from taxes}

According to their headquarters agreements, EAs are exempt from all direct taxes in respect to their premises ${ }^{101}$, assets and income ${ }^{102}$. They are also exempt from the payment of indirect taxes on goods purchased and services provided to them for official use ${ }^{103}$.

The exemption from the payment of indirect taxes must be applied either by direct exemption or by a refund of the tax already paid in accordance with the procedures set out in national legislations on exemption from indirect taxes set out for the official use of international organisations ${ }^{104}$ or Representation of the $\mathrm{EU}^{105}$ or diplomatic missions ${ }^{106}$. The agreement on the headquarters of GNSS in the case of VAT and excise duties on intraUnion purchases of goods and services provides for a system of direct exemptions in accordance with Directive 2006/112/EC ${ }^{107}$ on the common system of VAT, and Directive 2008/118/EC ${ }^{108}$ concerning the general arrangements for excise duty.

\subsection{Privileges and immunities conferred on EA personnel}

With respect to the privileges and immunities of EA personnel, headquarters agreements usually recall the provisions of Articles 11-15 and Article 17 of the PPI. As a result, the personnel of EAs, irrespective of their nationality, enjoy privileges, immunities, exemptions and facilities necessary to perform all duties and functions of his/her office without obstacles $^{109}$. In most cases, members of staff are treated as diplomatic agents of comparable rank, in accordance with the rules of international

ACER-SLO: Article 7(1).

EBA-GB: Article 8(1).

103 According to Article IX(2)(d) of the Europol-NL seat agreement, this exemption includes excise duties included on the price of alcoholic beverages (similarly Eurojust-NL: Article 8(2)(e)).

104 ACER-SLO: Article 7(4), ECDC-S: Article 4(2).

105 BEREC-LV: Article 8(3).

106 CEPOL-H: Article 6(2).

107 OJ L-347/1.

108 Council Directive 2008/118/EC concerning the general arrangements for excise duty and repealing Directive 92/12/EC, OJ 14.1.2009, L-9, p. 12.

109 GNSS-CZ: Article 13(1).
} 
law. In particular, they have immunity from arrest, detention and jurisdictional immunity with respect to their texts, words and acts carried out in the performance of their official duties. In addition to this, members of staff are exempt from national taxes on salaries, wages and emoluments paid by the EA in question.

Members of the statutory staff enjoy exemption from regulations restricting immigration and formalities for the registration of foreigners ${ }^{110}$. The ACER-SLO headquarters agreement provides that, during the discharge of their functions (and for six months after their termination), the staff of ACER, and their family members, are exempt from the requirement to obtain a residence permit if they are citizens of countries that are not members of the European Economic Area (EEA), or a document attesting the residence registration if they are citizens of member countries of the EEA ${ }^{111}$.

When they first take up their positions, members of staff of the EAs are also entitled to import personal effects from the country of their last residence, or from the country of which they are nationals, free of any customs duties or taxes. In addition to this, statutory staff of EAs (provided that they are not nationals of a receiving Member State) are entitled to VAT exemptions for purchasing personal and household effects when they first take up their post at the agency, and for a period of one year starting from the date of their appointment ${ }^{112}$. On the other hand, some headquarters agreements provide for VAT reimbursement (or exemption) with respect to products listed in their annexes ${ }^{113}$. What is particularly surprising is that the same product (e.g. a video camera) may be exempt from VAT in one agreement (BEREC-LV) but not in another (EASO-M). Additionally, some headquarters agreements provide that members of staff of EAs have the right to acquire one motor vehicle per household once every three years (for personal use), without VAT and/or duty ${ }^{114}$.

Particular privileges and immunities are granted to EAs' executive directors and their family members, as they enjoy privileges and immunities, exemptions and facilities in the receiving Member State similar to those

110 EASO-M: Article 8(3)(b).

111 ACER-SLO: Article 8(4).

112 On the tax privileges of ECHA's personnel see: J. Frände, M. Wallin, K. Äimä, Finland, [in:] M. Lang, P. Pistone, J. Schuch, C. Staringer, A. Storck (eds.): “Tax Rules in Non-tax Agreements", IBFD, Amsterdam 2012, pp. 308-309.

113 BEREC-LV, EASO-M.

114 GNSS-CZ: Article 13(6). 
accorded to the heads of diplomatic missions and members of their families in accordance with the Vienna Convention on Diplomatic Relations of $18.4 .1961^{115}$, provided that they are not nationals (residents) of a receiving Member State ${ }^{116}$. Exceptionally, some headquarters agreements provide for diplomatic privileges of their directors (and their family members) notwithstanding nationality ${ }^{117}$.

There are also provisions on national experts seconded to EAs by Member States, national regulatory agencies and other employers ${ }^{118}$. Emoluments, allowances and other payments paid to seconded national experts are exempt from national taxes, they have the right to a tax refund, they are entitled to export (after the date of ceasing to perform their functions) personal and household effects, including vehicles which are in their possession.

The Eurojust-NL headquarters agreement also relates to the specific legal status of national members seconded by each Member State in accordance with its legal system ${ }^{119}$. According to its Article 11, national members not being a Dutch member will be accorded, among other things, all the privileges and immunities accorded to heads of diplomatic missions accredited to the Kingdom of the Netherlands in accordance with the Vienna convention on Diplomatic Relations. Assistants to national members enjoy the privileges and immunities accorded to diplomatic agents ${ }^{120}$.

\subsection{Facilitations for communication}

Headquarters agreements provide that EAs may install and use their own communication technology systems. These should include necessary means to ensure the protection and confidentiality of personal data in accordance with EU law ${ }^{121}$. EAs are also entitled to use codes and to dispatch and receive official correspondence by courier or in sealed

15 UNTS vol. 500 p. 95.

116 ACER-SLO: Article 8(7), BEREC-LV: Article 11(5), CEPOL-H: Article 12(9), EASO-M: Article 8(7), ECDC-S: Article 7(4), ECHA-FIN: Article 8(4), EFRA-A: Article 4(2).

117 Europol-NL: Article XII(2), GNSS-CZ: Article 13(1).

118 BEREC-LV: Article 12, CEPOL-H: Article 13.

119 Council Decision 2002/187/JHA setting up Eurojust with a view to reinforcing the fight against serious crime, OJ 6.3.2002, L-63, p. 1, Article 2.

120 Eurojust-NL: Article 13.

121 ECHA-FIN: Article 4(1). 
bags ${ }^{122}$. Generally, with regard to official communications, EAs should be treated by the receiving Member State no less favourably than other international organisations ${ }^{123}$ or diplomatic representations in that Member State ${ }^{124}$. Some headquarters agreements expressly provide for the possibility of the EA installing and using a wireless transmitter with the consent of the government ${ }^{125}$.

\subsection{Support for the headquarters of EAs}

In some headquarters agreements there are provisions concerning support from the host state for the seat of the EA. As a rule, host states are obliged to provide full institutional support for the organisation and work of EAs ${ }^{126}$. This obligation in particular relates to making available temporary premises that are suitable for hosting the EA's staff and archives (usually free of charge) ${ }^{127}$ or supplying water, electricity, central heating/air conditioning to the premises of the $\mathrm{EA}^{128}$. Host states are also obliged to enter into discussions with the relevant stakeholders on the provision of appropriate transport connections to/from the city of the headquarters ${ }^{129}$.

\subsection{Flags, emblem and vehicles of EAs}

According to their headquarters agreements, EAs are authorised to fly the flag of the EU and a flag with the EA's emblem on their premises ${ }^{130}$. In addition to this, in conformity with the applicable laws and regulations of the host state, EAs may display their emblems on their official cars.

126 ACER-SLO: Article 15, BEREC-LV: Article 3, CEPOL-H: Article 3.

127 ACER-SLO: Article 15(2), EASO-M: Article 16(4), eu-LISA-A: Article 2(4), GNSS-CZ: Article 5.

128 Frontex-GR: Article 3(2).

129 ACER-SLO: Article 14, EASO-M: Article 11.

130 Europol-NL: Article X, Eurojust-NL: Article 9, GNSS-CZ: Article 6, CEPOL-H:
} Article 7. 
Most headquarters agreements include separate provisions on EA vehicles ${ }^{131}$, which provide for an exemption from any taxes, duties and import restrictions on vehicles which are intended to be used for the official purposes of the EA. EAs are usually exempt from road tax and their vehicles are normally registered under the same rules used for diplomatic missions accredited in the host state ${ }^{132}$. It should also be mentioned that particular privileges and immunities of vessels/airplanes owned or leased by Frontex consist in the possibility of mooring/landing at ports/airports in Greece ${ }^{133}$.

\subsection{Settlement of disputes}

All disputes relating to the application of headquarters agreements should normally be settled by direct negotiations and, if that fails, the dispute would be either referred to the $\mathrm{CJEU}^{134}$ or to the arbitration tribunal ${ }^{135}$. The GNSS-CZ headquarters agreement states that, in this context, the case may be referred by either party "to courts of competent jurisdiction" which include the CJEU. In most cases, headquarters agreements do not provide a legal basis for referring the case to the CJEU, but Article 17 of the EIOPA-D agreement mentions Article 272 TFEU in that context ${ }^{136}$. For the time being, there have not been any judgments of the CJEU concerning EA headquarters agreements. The only case so far that was brought to the CJEU pursuant to an EA headquarters agreement

131 BEREC-LV: Article 10, Cepol-H: Article 10, EMSA-P: Article 5, OHIM-E: Article 7.

132 Cepol-H: Article 10(3), OHIM-E: Article 7(3).

133 Frontex-GR: Article 6.

134 Few headquarters agreements provide for direct negotiations as the only way of resolving disputes (e.g. EFRA - A: Article 11). There are also agreements that provide for sending the dispute to a 'committee' designated by both sides, before the dispute is referred to the CJEU (see Frontex-GR: Article 10).

135 Eurojust-NL: Article 23, Europol-NL: Article XIX, EBA-GB: Article 18, CFCA-E: Article 12.

${ }^{136}$ According to Article 272 TFEU “The Court of Justice of the European Union shall have jurisdiction to give judgment pursuant to any arbitration clause contained in a contract concluded by or on behalf of the Union, whether that contract be governed by public or private law". 
concerned a dispute between EMSA and Portugal ${ }^{137}$, but it was subsequently removed from the list of cases ${ }^{138}$.

With respect to arbitration, Article 18 of the EBA-GB headquarters agreement stipulates, for example, that "any dispute [...] which is not settled by negotiation or some other agreed method, shall be referred for final decision to a tribunal of three arbitrators, at the request of either Party." Each party appoints one arbitrator, and the selected arbitrators together choose the chair of the tribunal ${ }^{139}$. Unless the parties agreed otherwise, the arbitration tribunal determines its own procedure.

\subsection{Supplemental or additional agreements}

Some headquarters agreements contain express provisions for the conclusion of supplemental or additional agreements ${ }^{140}$. The EFRA-A agreement provides that access to the commissary for EFRA's staff is regulated in the supplemental agreement ${ }^{141}$. The BEREC-LV headquarters agreement stipulates that buildings and installations used by the BEREC Office are to be described in a memorandum of understanding that will also include "the requirements, conditions and specifications to which the premises should respond as well as the conditions for the occupation by the BEREC Office"142. Similarly, the Frontex-GR headquarters agreement provides for an exchange of letters between Frontex and the Hellenic Ministry of Citizen Protection to define suitable office premises, which Greece will offer to the Frontex Operational Office in Piraeus ${ }^{143}$.

137 EMSA v. Portugal, Case T-4/08, Action brought on 3.1.2008, EU:T:2009:23, OJ 19.7.2008, C-183, p. 21.

138 EMSA v. Portugal, Case T-4/08, Order of the Court of First Instance of 29.1.2009, OJ 4.4.2009, C-82, p. 35.

139 If one of the parties fails to appoint an arbitrator within two months, the other party may request the President of the CJEU or (in his absence) the Vice-President, to make the appointment.

140 EFRA-A: Article 4(1)(d), BEREC-LV: Article 3(2).

141 This agreement has been concluded in the form of letters exchange, see BGBL III 15.2.2012, no. 37 .

142 For the text of the agreement, see: Latvijas Vēstnesis, no. 50 (4653), 28.3.2012.

143 Frontex-GR: Article 2(1), similarly eu-LISA-A: Article 2. 


\subsection{International responsibility}

Some headquarters agreements directly exclude any international responsibility of the host state resulting from the acts or omissions of the EA, its Director, statutory staff or seconded national experts on the host state's territory ${ }^{144}$. Unfortunately, those provisions do not specify who bears international responsibility instead of the host Member States, be it the EA concerned or the EU itself? They also seem to be ineffective with regard to international responsibility resulting from a breach of human rights obligations by the $\mathrm{EA}^{145}$.

\subsection{Entry into force}

EA headquarters agreements contain final provisions relating to their entry into force. This usually requires the receipt of notifications by which the host Member State and EA inform each other of the completion of (constitutional) procedures (formalities) required for its entry into force ${ }^{146}$. The procedures in question may consist in parliamentary approval ${ }^{147}$ and/or ratification by the president ${ }^{148}$ in the case of host states and the decisions of administrative boards in the case of EAs ${ }^{149}$. Some

144 EFSA-I:Article 5, CEPOL-H: Article 20, ENISA-GR: Article 5, eu-LISA-EST: Article 22.

145 C. Ryngaert, Oscillating Between Embracing and Avoiding Bosphorus: the European Court of Human Rights on Member State Responsibility for Acts of International Organisations and the Case of the EU, 'European Law Review' 2014, vol. 39, no 2, p. 176, E. Paasivirta, P. J. Kuijper, Does One Size Fit All?: The European Community and the Responsibility of International Organizations, 'Netherlands Yearbook of International Law' 2005, no. XXXVI, pp. 169, 192-196.

146 ACER-SLO: Article 19, ECDC-S: Article 17(2).

147 eu-LISA-A agreement has been approved by the Austrian National Council according to the Article 50(1)(1) of Austrian Federal Law, see Bundesgesetzblatt für die Republik Österreich, Teil III, 279/2013.

148 With respect to the GNSS-CZ agreement see Sbírka mezinárodních smluv č. 74/2012, p. 1626.

149 See, for example, Decision of ACER's Administrative Board no. 07/2010 Authorising the Director to sign the Seat Agreement with the Government of Republic of Slovenia, http://www.acer.europa.eu/en/the_agency/Organisation/Administrative_Board/ Administrative\%20Board\%20Decision/Decision\%20AB\%2007-2010\%20Seat\%20 Agreement\%20with\%20Gov.\%20of\%20Slovenia.pdf (accessed 4.4.2017). 
headquarters agreements do not require specific procedures and enter into force upon being signed ${ }^{150}$, or a specified day following $i^{151}$.

\section{Legal character of EA headquarters agreements}

The explanation of the legal character of EA headquarters agreements is genuinely 'not an easy matter' ${ }^{152}$. Their content, however, demonstrates that they all have binding legal force and, according to this author, they potentially may be treated either as international treaties or public law contracts, or administrative agreements.

\subsection{EA headquarters agreements as treaties}

The most decisive argument for treating EA headquarters agreements as international treaties is the practice of Member States as parties to these agreements, which usually ratify/approve these agreements according to their constitutional requirements. As has already been noted, headquarters agreements are usually published in national official gazettes according to the rules provided for in treaties. Moreover, some host states have registered EA headquarters agreements at the UN Secretariat in conformity with Article 102 of the UN Charter. These states include: Denmark with respect to the agreement with the EEA of $10.5 .1995^{153}$, and its additional protocol of 22.11.2005 $5^{154}$, Austria with respect to the agreement with EUMC of $18.5 .2000^{155}$, the UK with respect to the agreement with CEPOL of $30.12 .2004^{156}$, the Netherlands with respect to agreements with Europol

150 EBA-GB: Article 20(1).

151 EASO-M: Article 20.

152 This formulation was used by the AG Jääskinen with respect to the explanation of the legal nature of ECB's headquarters agreement, see opinion delivered on 24.5.2012 Land Hessen v Florence Feyerbacher, Case C-62/11, EU:C:2012:305, para. 37.

153 UNTS vol. 1889, no. 32150, p. 311.

154 Secretary-General of the United Nations: Certificate of registration no. 53582, 24.3.2006. UNTS vol. 2363, p. 515.

155 Secretary-General of the United Nations: Certificate of registration no. 49721, 30.1.2003. UNTS vol. 2203, p. 373, no. 39124.

156 Secretary-General of the United Nations: Certificate of registration no. 52496, 18.7.2005. UNTS vol. 2324, p. 3, no. 41636. 
of $1.11 .1998^{157}$ and Eurojust of $15.3 .2006^{158}$, and Finland with respect to the agreement with ECHA of 28.6.2007 ${ }^{159}$. The agreement between Spain and CFCA of 19.7.2008 was also registered ${ }^{160}$, but in the application for its registration, Spain indicated the other party as being CFCA and the European Community jointly ${ }^{161}$. The EU-OSHA-E agreement was, however, registered by Spain as if it was concluded with the EU solely ${ }^{162}$.

The intention of the registering states is rather clear and speaks for treating headquarters agreements as treaties. On the other hand, it should also be noted that the fact of registering headquarters agreements in accordance with the UN Charter does not automatically transform them into treaties, but it is not without significance. The UN Secretariat examines whether, in accordance with the general principles of international law and with the practice already developed, an international instrument submitted for registration constitutes an international agreement or not ${ }^{163}$. Therefore, the functions of the UN Secretariat are not purely ministerial and they must extend to a legal determination of what constitutes a "treaty" or "international agreement" ${ }^{164}$. The question whether those Member States that have not registered EA headquarters agreements at the UN Secretariat are in breach of Article 102 of the UN Charter is, therefore, open ${ }^{165}$.

157 Secretary-General of the United Nations: Certificate of registration no. 52530, 26.7.2005. UNTS vol. 2323, p. 439.

158 Secretary-General of the United Nations: Certificate of registration no. 55036, 9.3.2007. UNTS vol. 2418, p. 203, no. 43638.

159 Secretary-General of the United Nations: Certificate of registration no. 57451 , 28.1.2009.

160 UNTS, no. I-48675.

161 Secretary-General of the United Nations: Certificate of registration no. 60967, 13.7.2011.

162 Secretary-General of the United Nations: Certificate of registration no. 65559, 13.8.2015.

163 E. Martens, Ch. XVI Miscellaneous Provisions, Article 102, [in:] B. Simma, D-E Khan, G. Nolte, A. Paulus, N. Wessendorf (eds) 'The Charter of the United Nations: A Commentary', Volume II 3rd Edition, Oxford University Press, Oxford 2012, p. 2093. 164 M. Brandon, Analysis of the Terms "Treaty" and "International Agreement" for Purposes of Registration under Article 102 of the United Nations Charter, 'American Journal of International Law' 1953, vol. 47, no. 1, p. 49, at p. 53.

165 According to Aust, however, "non-registration is not necessarily evidence of lack of an intention to conclude a treaty," see A. Aust, Modern Treaty Law and Practice, 3rd edition, Cambridge University Press, Cambridge 2013, p. 48. 
We should also be reminded that some headquarters agreements expressly mention that they are governed and interpreted under international $\mathrm{law}^{166}$, which strengthens the presumption of their international nature.

On the part of EAs, examples of similar practice confirming that headquarters agreements are treaties are rather rare. In its action brought to the CJEU, the EMSA maintained, however, that the EMSA-P headquarters agreement "is an instrument of public international law within the sphere of Community law, and cannot be modified or changed unilaterally by Portugal [...]"167.

If, taking into account the practice of the host states and (some) EAs, we consider headquarters agreements as treaties, then an additional question may arise as to who the other party to them is. To put it differently, should we recognise EAs as parties to their headquarters agreements, or should it be the EU per se?

The question of EAs' independent treaty capacity is not definitely resolved in EU law, since the acts establishing EAs endow them with a legal personality and legal capacity, which is restricted to the legal systems of Member States ${ }^{168}$, while it is the EU that, according to Article 47 TEU, has international legal personality ${ }^{169}$. In scholarly literature, it is maintained that, despite the lack of clear legal provisions in this respect, EAs do have treaty capacity, though restricted to the possibility of concluding their headquarters agreements ${ }^{170}$. For some authors, EAs may even be recognised as subjects of international law ${ }^{171}$ that are competent to enter into binding

166 GNSS-CZ: Article 17.

167 EMSA v. Portugal, Case T-4/08.

168 Normally, acts establishing EAs state that the Agency shall be a body (agency) of the EU. It shall have legal personality. "In each of the Member States, the Agency shall enjoy the most extensive legal capacity accorded to legal persons under their laws. It may in particular, acquire or dispose of movable and immovable property and may be party to legal proceedings [...]", see, for example, Council regulation (EU) No. 2016/794 establishing Europol, Article 62.

169 Article 1(1) of the ERA-GR agreement stated however that "The Agency has international legal personality."

170 M. Fink, Frontex Working Arrangements: Legitimacy and Human Rights Concerns Regarding 'Technical Relationships', 'Utrecht Journal of International and European Law' 2012, vol. 28, no. 75, p. 20, at p. 26.

171 G. Schusterschitz, op. cit., p. 188 
agreements with third states and other international organisations ${ }^{172}$. On the other hand, however, there are also authors who deny that EAs are subjects of international law ${ }^{173}$. According to the Commission, although EAs do not have an international personality, they need to conclude headquarters agreements. That is why EU-OSHA "must therefore be considered to have necessary implicit capacity to act in the context of an agreement that is necessary in order for it to fulfil its tasks" ${ }^{174}$. The practice of Member States prima facie proves that the majority of them regard EAs as subjects of international law, since the majority of headquarters agreements are concluded with EAs as their sole parties ${ }^{175}$.

This author, however, does not share the view that EAs are subjects of international law. It is true that the question of whether or not international organisations have the capacity to create new subjects of international law is still unresolved, and that the doctrine of implied powers may implicitly confirm this capacity even in the absence of any legal basis in this respect ${ }^{176}$. Nevertheless, the international practice proves that the creation of a new subject of international law by an existing international organisation would require an explicit decision "whose entry into force depends on the subsequent ratification process of future Member States" ${ }^{177}$. In any case, contrary to certain opinions ${ }^{178}$, customary law may not be regarded as a source of international legal personality for EAs, since not all Member States treat EAs as international organisations ${ }^{179}$.

Bearing this in mind, the other available option is the recognition of the idea of 'split international personality' of the EU, where its subsidiary

172 R. A. Wessel, The EU as a party to international agreements: shared competences, mixed responsibilities, [in:] A. Dashwood, M. Maresceau (eds) 'Law and Practice of EU External Relations. Salient Features of a Changing Landscape', Cambridge University Press, Cambridge 2008, p. 174.

173 A. Ott, E. Vos, F. Coman-Kund, EU agencies and their international mandate: A new category of global actors? 'CLEER Working Papers' 2013, no. 7, p. 14.

174 European Commission (Employment, Social Affairs and Inclusion DG) Letter

to the Permanent Representative of Spain to the European Union, [5].

175 With the exception of Spain and Ireland.

176 C. Walter, Subjects of International Law, 'Max Planck Encyclopaedia of Public International Law' May 2007, [14].

177 K. Schmalenbach, International Organisations or Institutions, General Aspects, 'Max

Planck Encyclopaedia of Public International Law' July 2014, [5].

178 G. Schusterschitz, op. cit., p. 186.

179 See footnote 175. 
organs may act in international relations in the name of the $\mathrm{EU}^{180}$. The idea of the EU's 'split personality' seems to be confirmed by the practice of Spain and Ireland, which, as parties to the EAs' headquarters agreements concluded by them, constantly denote the EU and the EA concerned, whose name is given in parenthesis. This seems to mirror the practice of some UN subsidiary bodies ${ }^{181}$, which at times act as the only parties to their headquarters agreements, at other times the name of the UN appears as a party next to the name of the authority ${ }^{182}$. Within this context, scholarly literature also underscores that the headquarters agreement between the ECB and Germany has, in fact, been concluded by the EU and may be regarded as an additional source of its privileges and immunities in Member States ${ }^{183}$.

It should also be added that some headquarters agreements directly exclude host states' international responsibility for the activities, acts and omissions of the EAs that have a seat in their territory. This seems to confirm that the EU should be regarded as a party to EA headquarters agreements, as EAs cannot alone bear international responsibility because they are not international organisations, at least within the meaning of the Articles on the Responsibility of International Organisations ${ }^{184}$.

The legal basis for the conclusion of headquarters agreements as treaties may be found primarily in Article 18 of the PPI. In his opinion, in case C-220/03 AG Stix-Hackl said, with respect to ECB, that

As far as ECB is concerned, the Protocol on privileges and immunities is an authorising instrument, on the basis of which it is able independently to conclude agreements governed by public international law with the Member States. The ECB used that authority to negotiate the headquarters agreement, whose provisions

180 G. B. Burdeau, France [in:] A. Reinisch (ed.) 'The Privileges and Immunities of International Organizations in Domestic Courts', Oxford University Press, Oxford 2013, p. 112.

181 A. J. Miller, The Privileges and Immunities of the United Nations, 'International Organizations Law Review' 2009, vol. 6, no. 1, p. 7, at p. 34.

182 See, for example, footnote 7.

183 S. Barbier, M. Cuq, Les immunités de l'Union européenne [in:] M. Benlolo-Carabot, U. Candas, E. Cujo (eds) 'Union européenne et Droit International', Editions A. Pedone, Paris 2012, p. 410.

184 UNGA, A/RES/66/100, 27.2.2012, Annex, Article 2(a). 
give specific definition to the more general provisions of the Protocol on privileges and immunities $[. . .]^{185}$.

It should be recalled that very similar international agreements (arrangements) concerning the privileges and immunities of EU delegations in host countries, international organisations, or third countries may be entered into by the High Representative (HR) for Foreign and Defence Policy $^{186}$. Scholarly literature emphasises that this treaty capacity is "understandable and justified", since the HR has authority over the EU delegations that are part of its Service ${ }^{187}$. In spite of this, no one regards $\mathrm{HR}$ as a subject of international law.

\subsection{EA headquarters agreements as EU public law contracts}

The second option to explain the legal nature of EA headquarters agreements is to treat them as 'public law contracts'. This concept was proposed by AG Jääskinen in opinion in case C-62/11 with respect to the legal nature of the ECB's headquarters agreement ${ }^{188}$. In this case, a German court referred to the CJEU the question as to whether the ECB's headquarters agreement is part of EU law that takes precedence over national law, or whether it constitutes an international treaty ${ }^{189}$. In its judgment, the CJEU recognised, contrary to the arguments of the German government, that the ECB's headquarters agreement is a part of EU law. It said that the agreement in question "was concluded in order to define the privileges and immunities of the ECB in Germany", as laid down in the PPI, and it "implements principles" established by the PPI ${ }^{190}$. The CJEU,

185 European Central Bank v Germany, Case C-220/03, Opinion delivered on 13.9.2005, EU:C:2005:543, para. 52.

186 Council Decision No. 2010/427/EU establishing the organisation and functioning of the European External Action Service, OJ 3.8.2010, L-201, p. 30, Article 5(6).

187 M. Gatti, P. Manzini, External Representation of the European Union in the Conclusion of International Agreements, 'Common Market Law Review' 2012, vol. 49, no. 5, p. 1703, at p. 1731.

188 Land Hessen v Florence Feyerbacher, Case C-62/11, Opinion delivered on 24.5.2012, EU:C:2012:305.

189 Land Hessen v Florence Feyerbacher, Case C-62/11, Judgment of 19.7.2012, EU:C:2012:486, para. 31. See also, M. Larché, Accord de siége de la BCE, Europe no. 10, October 2012, comm. 365.

190 Land Hessen v Florence Feyerbacher, Opinion delivered on 24.5.2012, para. 34. 
however, did not justify its claims extensively. More arguments in favour of that claim were presented in the opinion of AG Jääskinen in this case. The AG pointed out that the categorisation of the ECB's headquarters agreement as a legal act "is not an easy matter", and in his opinion it could fall into two categories, namely: an international agreement "upon which the national law ratifying it confers the same status as national laws in the formal sense," or "an act forming part of European Union law and which, as such, takes precedence over national law" ${ }^{\prime 191}$. In the AG's opinion, the agreement should be attached to the legal system of the EU as it constitutes the implementation of the PPI and aims to set out the privileges and immunities granted in Germany to the $\mathrm{ECB}^{192}$. As a result, the $\mathrm{AG}$ admitted that the agreement is a part of EU law, "which constitutes the legal framework of reference for the purpose of interpreting its provisions" 193 and may be regarded as "public law contract for the purpose of the European Union law"194. According to the AG, this is confirmed by the wording of Article 21 of the ECB's headquarters agreement concerning the settlement of disputes, which refers to Article 35(4) of the Statute of the ESCB stipulating that the CJEU "shall have jurisdiction to give judgment pursuant to any arbitration clause contained in a contract concluded by or on behalf of the $\mathrm{ECB}$, whether that contract be governed by public or private law"195, which clearly relates to the terms used in Article 272 TFEU $^{196}$.

There are, however, certain important consequences resulting from regarding the ECB's headquarters agreement as a public law contract. A public law contract (like a private law contract) has a binding effect only on its parties. The ECB's headquarters agreement, therefore, specifies the respective rights and obligations of its parties (ECB and Germany), and cannot be regarded as an act having effect in relation to everyone

191 Ibid. para. 37.

192 Ibid. para. 46.

193 Ibid. para. 47.

194 Ibid. para. 48.

195 Protocol (no. 4) on the Statute of the European System of Central Banks and the European Central Bank, OJ 19.8.2016, C-202, p. 230.

196 According to which "The Court of Justice of the European Union shall have jurisdiction to give judgment pursuant to any arbitration clause contained in a contract concluded by or on behalf of the Union, whether that contract be governed by public or private law." 
(erga omnes) in the context of EU law ${ }^{197}$, like other EU institutions or individuals ${ }^{198}$. However, in the words of AG Jääskinen:

it seems appropriate to compare the effects of Headquarters Agreement with those of directives as far as individuals are concerned. Like a directive, which cannot of itself impose obligations on an individual and cannot therefore be relied upon as such against an individual, the Headquarters Agreement cannot adversely affect the rights of individuals under the European Union law or national legislation ${ }^{199}$.

Such an assumption, however, clearly goes against the position of Germany, which ratified the headquarters agreement ${ }^{200}$, and to the views of some officials of the ECB's legal service, who maintain that it is 'an agreement under public international law and is binding on the German legislator and the German authorities' ${ }^{201}$.

In this author's opinion, the arguments put forward by AG Jääskinen may be taken into account while determining the legal nature of the EAs' headquarters agreements. There are, however, two important factors that leave the AG's argumentation susceptible to criticism. Firstly, the AG deduced that the ECB's headquarters agreement is a part of EU law from the fact that it contains a clause providing for the settlement of disputes by the CJEU. In EA headquarters agreements, however, such a clause appears in about half of them. In other cases, EA headquarters agreements provide for various ways of resolving disputes, such as arbitration, for example. On the other hand, it should be recalled that in the T-4/08 case, EMSA maintained that the jurisdiction of the CJEU to give judgment pursuant to the arbitration clause contained in a contract concluded by that agency is provided in the regulation establishing $\mathrm{EMSA}^{202}$. A similar provision is included in the founding acts of other EAs. Secondly, as a public law contract, the ECB's headquarters agreement cannot have legal effects in

197 Land Hessen v Florence Feyerbacher, Opinion delivered on 24.5.2012, para. 49.

198 Ibid. para. 51.

199 Ibid. para. 52.

200 Gesetz zu dem Abkommen vom 18. September 1998 zwischen der Regierung der Bundesrepublik Deutschland und der Europäischen Zentralbank über den Sitz der Europäischen Zentralbank, Bundesgesetzblatt 1998 Teil II, No. 51, p. 2995.

201 G. Gruber, M. Benisch, Privileges and Immunities of the European Central Bank, 'European Central Bank Legal Working Paper Series', no. 4/June 2007, p. 6.

${ }^{202}$ Regulation (EC) No. 1406/2002 of the European Parliament and of the Council establishing a European Maritime Safety Agency, OJ 5.8.2002, L-208, p. 1, Article 8(2). 
relation to individuals. This is not true, however, with regard to many EAs' headquarters agreements, as they contain numerous provisions relating directly to the EA's personnel or third persons, establishing rights and/or obligations for them, especially when they allow individuals to be expelled or excluded from the EA's premises for a breach of the regulations or for being considered undesirable ${ }^{203}$.

\subsection{EA headquarters agreements as administrative agreements}

One of the possible proposals for resolving the problems of a legal nature of EA headquarters agreements is to regard them as administrative agreements. It should be pointed out that, within this context, some headquarters agreements directly confirm their administrative character. The preamble to the EMSA-P agreement states, for example, that it contains "further administrative provisions" made for the implementation of the relevant articles of the PPI.

Administrative agreements are an established part of binding Union law ${ }^{204}$. In his opinion, in case C-327/91, AG Tesauro defined them as "agreements in a simplified form, which, on the basis of the internal law of most States, are concluded by the executive, without parliamentary action, and normally concern - if we exclude secret arrangements technical and administrative matters, whose implementation does not entail legislative amendments or which supplement or define pre-existing agreements concluded in accordance with the usual procedures, when they accordingly form part of the legislative framework established by other agreements" ${ }^{205}$. This definition seems to cover EA headquarters agreements from the point of view of EAs, but from the point of view of Member States it is not acceptable at all. Most Member States ratify EA headquarters

203 See footnotes 95 and 96.

204 Administrative arrangements are also defined as "non-binding arrangements that are functional to the cooperation between the administration of the Union and the administration of third countries or international organizations," see M. Gatti, P. Manzini, op. cit., p. 1732.

205 France v Commission, Case C-327/91, Opinion of Advocate General Tesauro delivered on 16.12.1993, ECLI:EU:C:1993:941, [32]. On this point see also F. A. Mann, Zur Auslegung von Verwaltungsabkommen durch den Bundesgerichtshof, 'Zeitschrift für ausländisches öffentliches Recht und Völkerrecht', 1975, vol. 35, no. 1, p. 723. 
agreements according to their respective constitutional provisions, which proves that they do not regard them as administrative in nature. The reason for this seems to be that the agreements in question are asymmetric when it comes to the division of rights and obligations of their parties. They place so many obligations on the state parties to them that it requires their formal ratification/approval according to national constitutional procedures, and even registration at the UN Secretariat. In the case of the EU (EAs), there are no essential obligations besides consent to locate the seat of an EA on the territory of the Member State concerned.

\section{Conclusion}

Considering the legal nature of EA headquarters agreements, priority should be given to treat them as bilateral international agreements concluded between the EU (the EA in question) and a Member State, which may have an erga omnes effect. Headquarters agreements are not used as instruments for structuring international relations of the EU, hence they may be called "inner" international agreements ${ }^{206}$. The competence to conclude this sort of "inner bilateral" ${ }^{207}$ agreements results for the EU (EA in question) from the PPI (Article 18), and in some cases from the EAs' establishing acts.

The recognition of EA headquarters agreements as "inner bilateral" treaties has important consequences for the hierarchy of sources of EU

206 As opposed to "internal” international agreements concluded solely by Member States, see the Internal Agreement between the Representatives of the Governments of Member States of the European Union, meeting within the Council, on the financing of European Union aid under the multiannual financial framework for the period 2014 to 2020, in accordance with the ACP-EU Partnership Agreement, and on the allocation of financial assistance for Overseas Countries and Territories to which Part Four of the Treaty on the Functioning of the European Union applies, OJ 6.8.2013, L-210, p. 1.

207 According to this author, there are also "inner multilateral" international agreements in EU law, see, for example, the Guarantee Agreement between Member States and the EIB concerning loans to be made by the EIB in favour of projects in the African, Caribbean and Pacific States and in Overseas Countries and Territories, Polish OJ [Monitor Polski] 2012, Item 21, p. 52. This agreement has been signed by Poland with the consent of Polish government granted according to Polish Law on international agreements, see. Polish OJ [Monitor Polski] 2012, Item 22. 
law, since they clearly confirm they are subordinate to the $\mathrm{PPI}^{208}$ and EU secondary law (the EAs' establishing acts). At the same time, EA headquarters agreements form part of EU law, which take precedence over national law and which national courts have to apply.

As to their subject-matter, EA headquarters agreements mostly include provisions implementing the privileges and immunities of the EU provided for in the $\mathrm{PPI}^{209}$. There are, however, also stipulations that expand EA privileges and immunities beyond the frameworks resulting from the PPI, such as, for example, diplomatic status for their executive directors or unusually broad tax exemption for certain categories of staff ${ }^{210}$. This is hardly acceptable since, through the different treatment of members of its staff, the EU de facto enjoys a different legal status in every host Member State. EA headquarters agreements also contain provisions on the schooling of children of staff members, or on the establishment of necessary transport connections from the city of a seat. This demonstrates that EA headquarters agreements also serve as instruments for arranging the working conditions for members of an EA's staff.

A very peculiar feature of EA headquarters agreements consists in their systems of dispute resolution, since some of them relate to the jurisdiction of the CJEU, according to Article 272 TFEU, and some to ad hoc arbitration boards or tribunals ${ }^{211}$. As far as the former category is concerned, while it may be disputed whether international agreements fall within the meaning of "contracts" under Article 272 TFEU $^{212}$, the headquarters agreement between the ECB and Germany was nonetheless admitted by the CJEU on this basis ${ }^{213}$. More problematic, however, are the latter headquarters agreements, since the arbitration clause in international agreements

208 This has already been noticed with respect to the (expired) Protocol on the Privileges and Immunities of Europol, see R. van Alebeek, A. Nollkaemper, Privileges and Immunities of International Organizations in the case law of Dutch Courts, 'ACIL Research Paper' 201211, p. 14.

209 On the privileges and immunities of the EU see R. Wessels, Immunities of the European Union, 'International Organizations Law Review' 2014, vol. 10, no. 1, p. 395.

210 See footnote no. 112.

211 See footnote no. 136.

212 R. Lukits, Arbitration before the European Court of Justice, 'International Arbitration Law Review' 2014, vol. 17, no. 1, p. 1, at p. 9.

213 European Central Bank v Germany, Case C-220/03, EU:C:2005:748. 
concluded by the EU (EA) ${ }^{214}$ with a Member State may be contrary to the provisions of Article 4(3) TEU and Article $344 \mathrm{TFEU}^{215}$. According to the case law of the CJEU, "an international agreement [...] cannot affect the exclusive jurisdiction of the Court in regard to resolution of disputes between Member States concerning the interpretation and application of Community law" ${ }^{216}$. In this author's opinion, this should also apply to disputes resulting between Member States and the EU. Moreover, it also seems that such an arbitration clause contained in EA headquarters agreements does not exclude the jurisdiction of national courts according to Article $274 \mathrm{TFEU}^{217}$. As a result, this may also cause the concurrent jurisdiction of both national courts and arbitration tribunals established according to EA headquarters agreements.

The Commission's "Guidelines with standard provisions for headquarters agreements of the EU decentralised agencies" marked a good effort in the process of standardising EA headquarters agreements. In this author's opinion, however, the EU should adopt a binding legal act determining a framework for the conclusion of EA headquarters agreements ${ }^{218}$. Such an act could be adopted in the form of Union secondary law (e.g. a regulation) or, similarly to the agencies of the former second pillar, as a decision of the representatives of the governments of the Member States meeting within the Council, which would have to be ratified according to the Member States' constitutional requirements. This would enhance compatibility and consistency among EA headquarters agreements, as well as between them and the PPI. It could also prevent EAs from abusing their

214 R. Lukits, Arbitration under international agreements of the European Union, 'International Arbitration Law Review' 2015, vol. 18, no. 1, p. 7.

215 According to Article 344 TFEU, "Member States undertake not to submit a dispute concerning the interpretation and application of the Treaties to any other method of settlement other than those provided for therein."

216 Commission of the European Communities v. Ireland (Mox Plant), Case C-459/03, EU:C:2006:345, para. 132.

217 According to Article 274 TFEU "Save where jurisdiction is conferred on the Court of Justice of the European Union by the Treaties, disputes to which the Union is a party shall not on that ground be excluded from the jurisdiction of the courts or tribunals of Member States."

218 With respect to the International Criminal Court, see: Basic principles governing a headquarters agreement to be negotiated between the Court and the host Country, ICC-ASP/1/3. On this point, see also Z. Hetesy, The Making of the Basic Principles of the Headquarters Agreement, 'Fordham International Law Journal' 2001, vol. 25, no. 3, p. 625 . 
negotiating position towards Member States, and demanding from them excessive privileges and immunities while ensuring the necessary margin for manoeuvre to EAs and Member States.

\section{Bibliography}

1. Ahluwalia K., The Legal Status, Privileges and Immunities of the Specialised Agencies of the United Nations and Certain other International Organizations, Martinus Nijhoff,The Hague 1964.

2. Aust A., Modern Treaty Law and Practice, third edition, Cambridge University Press, Cambridge 2013.

3. Barbier S., Cuq M., Les Immunités de l'Union Européenne [in:] Benlolo-Carabot M., Candas U., Cujo E., (eds) 'Union Européenne et Droit International', Editions A. Pedone, Paris 2012.

4. Brandon M., Analysis of the Terms "Treaty" and "International Agreement" for Purposes of Registration under Article 102 of the United Nations Charter, 'American Journal of International Law' 1953, vol. 47.

5. Burdeau G. B., France [in:] Reinisch A., (ed.) 'The Privileges and Immunities of International Organizations in Domestic Courts', Oxford University Press, Oxford 2013.

6. Chamon M., EU Agencies. Legal and Political Limits to the Transformation of the EU Administration, Oxford University Press, Oxford 2013.

7. Churchill R. R., Ulfstein G., Autonomous Institutional Arrangements in Multilateral Environmental Agreements: a Little Noticed Phenomenon in International Law, 'American Journal of International Law' 2000, vol. 94.

8. Fink M., Frontex Working Arrangements: Legitimacy and Human Rights Concerns Regarding 'Technical Relationships', 'Utrecht Journal of International and European Law' 2012, vol. 28, no. 75.

9. Frände J., Wallin M., Äimä K., Finland, [in:] Lang M., Pistone P., Schuch J., Staringer C., Storck A., (eds), 'Tax Rules in Non-tax Agreements', IBFD, Amsterdam 2012.

10. Gatti M., Manzini P., External Representation of the European Union in the Conclusion of International Agreements, 'Common Market Law Review' 2012, vol. 49.

11. Gruber G., Benisch M., Privileges and Immunities of the European Central Bank, European Central Bank Legal Working Paper Series, no. 4/June 2007.

12. Hetesy Z., The Making of the Basic Principles of the Headquarters Agreement, 'Fordham International Law Journal' 2001, vol. 25.

13. Hofmann H. C. H, Morini A, Constitutional aspects of the pluralisation of the EU executive through "agencification", 'European Law Review' 2012, vol. 37 . 
14. Hofmann H. C. H., Agreements in EU Law, 'European Law Review' 2006, vol. 31.

15. Lukits R., Arbitration before the European Court of Justice, 'International Arbitration Law Review' 2014, vol. 17.

16. Lukits R., Arbitration under international agreements of the European Union, 'International Arbitration Law Review' 2015, vol. 18.

17. Mann F. A., Zur Auslegung von Verwaltungsabkommen durch den Bundesgerichtshof, 'Zeitschrift für ausländisches öffentliches Recht und Völkerrecht' 1975, vol. 35.

18. Martens E., Ch.XVIMiscellaneous Provisions, Article 102, [in:] Simma B., Khan D-E., Nolte G., Paulus A., Wessendorf N., (eds) 'The Charter of the United Nations: A Commentary', Volume II 3rd Edition, Oxford University Press, Oxford 2012.

19. Michaels D. B., International Privileges and Immunities: a Case for a Universal Statute, Martinus Nijhoff, The Hague 1971.

20. Miller A. J., The Privileges and Immunities of the United Nations, 'International Organizations Law Review' 2009, vol. 6.

21. Muller A. S., International Organizations and their Host States. Aspects of their Legal Relationship, Kluwer Law International, The Hague 1995.

22. Münch W., The Impact of Headquarters Agreements on Human Resources Management of the United Nations System, [in:] von Scholremer S., (ed.), 'Praxishandbuch UNO', Springer, Berlin Heidelberg New York 2003.

23. Ott A., Vos E., Coman-Kund F., EU agencies and their international mandate: A new category of global actors? 'CLEER Working Papers' 2013, no. 7.

24. Paasivirta E., Kuijper P. J., Does One Size Fit All?: The European Community and the Responsibility of International Organizations, 'Netherlands Yearbook of International Law' 2005, no. XXXVI.

25. Ruffert M., Personality under EU Law: A Conceptual Answer towards the Pluralisation of the EU, 'European Law Journal' 2014, vol. 20.

26. Ryngaert C., Oscillating Between Embracing and Avoiding Bosphorus: the European Court of Human Rights on Member State Responsibility for Acts of International Organisations and the Case of the EU, 'European Law Review' 2014, vol. 39.

27. Schmalenbach K., International Organisations or Institutions, General Aspects, 'Max Planck Encyclopedia of Public International Law' July 2014.

28. Schusterschitz G., European Agencies as Subjects of International Law, 'International Organizations Law Review' 2004, no. 1.

29. Szasz P. C, The Complexification of the United Nations System, 'Max Planck Yearbook of United Nations Law' 1999, no. 3.

30. Van Alebeek R., Nollkaemper A., Privileges and Immunities of International Organizations in the case law of Dutch Courts, 'ACIL Research Paper' no. 2012-11. 
31. Walter C., Subjects of International Law, 'Max Planck Encyclopedia of Public International Law' May 2007.

32. Wessel R. A., The EU as a party to international agreements: shared competences, mixed responsibilities, [in:] Dashwood A., Maresceau M., (eds) 'Law and Practice of EU External Relations. Salient Features of a Changing Landscape', Cambridge University Press, Cambridge 2008.

33. Wessels R., Immunities of the European Union, 'International Organizations Law Review' 2014, vol. 10.

34. Zieliński M., Porozumienie dotyczace siedziby agencji Unii Europejskiej Frontex w Polsce (aspekty konstytucyjne), 'Przegląd Sejmowy' 2016, vol. XXIV, no. 1(132). 